\title{
SAYYID USMAN DAN PANDANGAN KONTROVERSIALNYA TENTANG PEMERINTAH KOLONIAL BELANDA
}

\author{
Idan Dandi \\ UIN Syarif Hidayatullah Jakarta (idan.ilmiah@ gmail.com)
}

\begin{abstract}
The text is about the figure of Sayyid Usman who be a Betawi mufti and lived in the Dutch East Indies colonial times. The figure is a very influential person in his day, because his works can be printed in a very large amount with lithographic printing machine technology that he pioneered in Nusantara. Due to its very brilliant prestige, the colonial officials in Batavia also glanced at it. Not how long, Sayyid Usman was lined up to partner Christian Snouck Hurgronje as a colonial advisor. This study uses a sociological and an intellectual biographical approach. The use of the sociological approach aims to unveil all the motivations and purposes of Sayyid Usman's highly controversial ideas as opposed to the plurality of ideas that are present in that era. While the intellectual biographical approach has the purpose to reveal the various realities of life of the subject being studied, along with the influence it receives so that it becomes the thinking model in his mind. From the description, it is known that what was taught by Shaykh Al Misri (his grandfather) as a child is very influential on the development of Sayyid Usman's thought, including in view of colonial rule. His controversial ideas include supporting the status quo of the occupation of whites (Dutch East Indies) in the Indonesia.
\end{abstract}

Keywords: mufti, ulama, colonial advisor, thought, controversial

\begin{abstract}
Abstrak
Teks sederhana ini membahas mengenai sosok Sayyid Usman yang merupakan seorang mufti Betawi yang hidup di zaman penjajahan Hindia Belanda. Tokoh ini merupakan orang yang sangat berpengaruh di zamannya, karena karya-karyanya dapat tercetak dalam jumlah yang sangat besar dengan teknologi mesin cetak litograf yang dipeloporinya di bumi Nusantara. Akibat pamornya yang sangat cemerlang, pejabat kolonial di Batavia pun meliriknya. Tidak selang berapa lama, Sayyid Usman didapuk menjadi partner Christian Snouck Hurgronje sebagai penasehat kolonial. Studi ini menggunakan pendekatan sosiologis dan pendekatan biografik intelektual. Penggunaan pendekatan sosiologis bertujuan untuk menyingkap segala motivasi dan tujuan dari pemikiran-pemikiran Sayyid Usman yang sangat kontroversial karena bertentangan dengan pelbagai pemikiran yang jamak hadir di era tersebut. Sedangkan pendekatan biografik intelektual memiliki tujuan untuk mengungkapkan pelbagai kenyataan hidup dari subyek yang sedang tengah diteliti, beserta pengaruh yang diterimanya sehingga kemudian menjadi thinking model di dalam kepalanya. Dari uraian ini diketahui bahwa apa yang diajarkan oleh Syekh Al Misri (kakeknya) sewaktu kecil sangat berpengaruh terhadap perkembangan pemikiran Sayyid Usman, termasuk dalam memandang kekuasaan kolonial. Pemikiran-pemikirannya yang kontroversial itu di antaranya adalah mendukung ketetapan penjajahan orang kulit putih di bumi Nusantara.
\end{abstract}

Kata Kunci: mufti, ulama, penasehat kolonial, pemikiran, kontroversial 


\section{A. Pendahuluan}

Islam dan kolonialisme seakan tidak pernah dapat menyatu, bahkan acapkali dianggap sebagai ideologi yang menjadi penantang utama bagi penggerak arus penjajahan. Setidaknya itu yang terjadi di dalam konteks Nusantara, saat wilayah itu dijajah oleh para pendatang asal Eropa yang berwujud pemerintah kolonial Hindia Belanda.

Sejak awal kemunculannya pada dekade pertama abad ke-19, pihak penjajah memang sering berhadapan dengan unsur-unsur Islam saat hendak melakukan penetrasi kekuasaannya di tengah masyarakat. Kaum santri yang ikut serta dalam perang panjang di Cirebon merupakan salah satu contoh nyatanya. Kekuatan mereka dalam memegang panji-panji Allah agar bisa mandiri dan bebas ternyata mampu merepotkan para serdadu kolonial yang jauh lebih unggul dalam segala seginya. ${ }^{1}$ Meskipun kemudian perlawanan-perlawanan itu padam sebelum memasuki babak dekade ketiga abad ke-19, nyatanya ideologi anti penjajahan yang

Terkait peperangan ini, salah satu sumber yang dapat dibaca adalah sebuah tesis dari Universitas Indonesia. Baca, Ipik Ernaka, Perlawanan Bagus Rangin di Cirebon Tahun 1806-1812, Tesis tidak diterbitkan, (Jakarta: Program Pascasarjana Fakultas Ilmu Pengetahuan Budaya Universitas Indonesia, 2007). dimoroti Islam masih tetap hidup dan menyala-nyala.

Hal itu bisa dilihat dalam Perang Jawa, perang yang konon menjadi biang kerugian yang amat besar bagi pemerintah kolonial Hindia Belanda. Dalam perang tersebut, terdapat banyak kalangan agamawan dan ulama Islam yang berperan. Bahkan, sejarawan Indonesia asal Inggris, Peter Carey, mendaftar hampir seluruh kelompok Islam yang turut serta dalam peperangan di dalam karya monumentalnya. $^{2}$

Dari dua pengalaman yang amat sulit dilupakan itu, pemerintah kolonial Hindia Belanda mengambil kesimpulan bahwa agama Islam bisa menjadi sangat membahayakan bagi eksistensi mereka di tanah Nusantara. Terlebih apabila ajaran mengenai jihad yang ada di dalam agama itu disebarkan secara simultan di tengah para penganutnya, maka gerakan massa yang tidak sedikit bisa menjadi masalah besar bagi orang-orang Belanda. Dengan dasar itu, Islam dan para pemukanya seakan berkesan selalu jauh dari penjajah dan tidak mau berkompromi, karena tidak pernah

2 Lihat lebih lanjut, Peter Carey, The Power of Prophecy: Prince Dipanagara and the End of an Old Order in Java, 1785-1855, (Leiden: KITLV Press, 2007). 
mengambil jalan kooperatif dengan pihak kolonial Belanda.

Meskipun demikian, ternyata tidak semua pemuka Islam melakukan hal yang serupa. Beberapa di antaranya malah benarbenar mengambil jalan yang berbeda karena memberi dukungan atau pun menyanjung kekuasaan kolonial atas tanah Nusantara. Salah satu orang berpengaruh dari kalangan muslim yang dimaksud adalah Sayyid Usman ibn 'Abdillah ibn Yahya, seorang keturunan Arab Hadramaut dan Mesir yang konon silsilahnya terhubung hingga ke Nabi Muhammad SAW.

Sosok yang menjadi mufti Betawi ini merupakan salah satu ulama penting di era kolonial. Bahkan, Azra menyatakannya sebagai ulama keturunan Arab yang paling terkemuka di Nusantara pada akhir abad 19 dan awal abad 20. Hal itu dapat dilihat dari karirnya yang cemerlang, karena setelah karyakaryanya menjangkau khalayak yang luas, dia semakin dikenal oleh pejabat-pejabat Batavia dan kemudian mendapat posisi yang penting sebagai penasehat pemerintah di dalam struktur pemerintahan kolonial di kota yang menjadi pusat administrasi tersebut. ${ }^{3}$

3 Azyumardi Azra, "Hadhrami Scholars in The Malay-Indonesian Diaspora: A Preliminary
Saat itu, posisi mufti menjadi amat vital karena sosok tersebut merupakan palang pintu yang terakhir bagi keluarnya suatu fatwa yang hendak disosialisasikan kepada masyarakat. Predikat itu pun tidak sembarangan diberikan, karena hanya disandang oleh mereka yang memiliki kemampuan dan pengetahuan mumpuni dalam persoalan-persoalan hukum Islam.

Kedekatan Sayyid Usman dengan pihak kolonial seakan menjadi bantahan keras bagi wacana (atau mungkin) keyakinan mengenai ketidakselarasan antara ajaran Islam dan kolonialisme. Hal ini menjadi menarik karena selama ini mayoritas kaum muslim hanya tahu bahwa para pemuka Islam selalu memiliki sikap yang berbeda dengan para penjajah kulit putih. Ajaran hubbul wathon dan sejarah kelam perang dengan kaum Nasrani di pelbagai medan laga di Eropa dan Timur Tengah serta Afrika, tentu turut memengaruhi pola pikir masingmasing pihak tentang lawannya. Dengan kata lain, anggapan sebelumnya adalah seakan tidak mungkin ada orang Islam yang mau bekerjasama dengan pihak penjajah.

Berdasarkan semua uraian itulah akhirnya saya tertarik untuk Islamika (Jakarta, vol. 2. No. 2, 1995), hlm. 9. 
menelisik siapakah sebenarnya sosok Sayyid Usman tersebut dan bagaimana pemikirannya terkait Islam dan kolonialisme di Nusantara. Artikel ini sengaja ditulis untuk mengupas tokoh penting ulama Betawi yang memiliki pemikiran anti-mainstream di zamannya. Di saat yang lain dengan keras dan lantang menyerukan kalimat-kalimat yang sangat negatif terhadap kekuasaan kolonial, sang mufti Betawi malah mengambil sikap yang berbeda. Dengan otoritasnya sebagai pihak yang paling menentukan dalam persoalan hukum Islam, Sayyid Usman malah menjadi pendukung status-quo pemerintahan kolonial.

Tidak hanya itu, tulisan ini juga merupakan pengantar bagi pembaca atas pemikiran dan pemahaman yang diselami oleh Sayyid Usman dalam memandang persoalan-persoalan tertentu pada saat dirinya aktif sebagai seorang ulama saat pemerintahan kolonial dengan gagah tegak berdiri.

Teks yang berada di hadapan para pembaca ini merupakan hasil penelitian sederhana yang dilakukan mengenai sejarah pemikiran atau sejarah intelektual (intellectual history) seorang tokoh tertentu. Sejarah intelektual memberi penekanan terhadap pemikiran, ideide, atau nilai-nilai yang berpengaruh di dalam kehidupan umat manusia dari masa yang sangat lampau hingga di era kontemporer. Sebagai studi yang mandiri, sejarah intelektual baru banyak diperbincangkan orang pada awal abad ke-20. ${ }^{4}$ Pada waktu itu, sejarah jenis ini mulai banyak ditulis orang karena banyak sosok-sosok yang menarik dan patut dikupas pemikirannya. Tokoh-tokoh yang dimaksud tidak hanya memiliki pengaruh yang sangat besar, melainkan pula memiliki pemikiran besar yang terus berkembang dari waktu ke waktu, turut membangun peradaban umat manusia di muka bumi ini.

Adapun pendekatan yang digunakan dalam penelitian ini adalah pendekatan sosiologis dan pendekatan biografik intelektual. Pendekatan sosiologis sendiri merupakan pendekatan yang memberi penekanan terhadap aspekaspek pola hubungan sosial di dalam masyarakat. Interaksi dan relasi antar individu di tengah aktivitas kesehariannya, merupakan hal-hal yang perlu digarisbawahi di dalam pendekatan ini. Sedangkan pendekatan biografik intelektual merupakan suatu pendekatan yang memiliki arah terhadap usaha untuk

\footnotetext{
4 Lihat, Leo Agung, Sejarah Intelektual,
} (Yogyakarta: Penerbit Ombak, 2013). 
mengungkapkan pelbagai kenyataan hidup dari subyek yang sedang diteliti, pengaruh yang diterima subyek pada masa formatif di dalam kehidupannya, serta sifat dan watak subyek terhadap perkembangan suatu aspek kehidupan. ${ }^{5}$ Pendekatanpendekatan tersebut menjadi penting guna mengunkap kisah perjalanan hidup Sayyid Usman, serta pelbagai latar belakang yang dimilikinya.

Di samping itu, aspek-aspek sosial kultural yang hendak diketahui keberadaannya pun bisa terungkap lewat pendekatan sosiologis tersebut, ${ }^{6}$ mengingat pendekatan ini memang sangat cocok guna menyingkap segala motivasi dan tujuan dari pemikiran-pemikiran Sayyid Usman yang sangat kontroversial karena bertentangan dengan pelbagai pemikiran yang jamak hadir di era tersebut.

\footnotetext{
${ }^{5}$ Sidi Gazalba, Pengantar Sejarah Sebagai Ilmu (Jakarta: Bhatara, 1996), hlm. 177.

6 Menurut Weber, tujuan penting dari penggunaan pendekatan sosiologis di dalam kajian historis itu adalah demi terbentuknya pemahaman mengenai makna subjektivitas di dalam perilaku-perilaku sosial. Dengan demikian, yang mesti digarisbawahi adalah tujuan dari seorang individu dalam melakukan sebuah tindakan yang berkaitan dengan peristiwa-peristiwa kolektif. Baca, Dudung Abdurahman, Metodologi Penelitian Sejarah Islam (Yogyakarta: Ombak, 2011) hlm. 12.
}

\section{B. Perjalanan Hidup Sayyid Usman}

Nama lengkap Sayyid Usman adalah Sayyid 'Uthmān ibn 'Abdillāh ibn 'Āqil ibn Yahyā al'Alāwī. Ia dilahirkan pada tanggal 1 Desember 1822, di tengah-tengah masyarakat Arab Batavia. Ayahnya adalah 'Abdullah bin Aqil bin Umar bin Yahya yang berasal dari wilayah Hadramaut dan kemudian pergi kembali ke tanah Arab pada saat Sayyid Usman berusia tiga tahun. Sedangkan ibunya, Aminah, merupakan keturunan seorang syekh asal Mesir yang sangat masyhur di wilayah Petamburan karena menjadi seorang ulama masyarakat disana, yaitu Syekh 'Abd al-Raḥmān bin Ahmad al-Mișrī.

Dari namanya yang berlabel "sayyid" dapat diketahui bahwa ia dipercayai memiliki garis keturunan yang tersambung hingga Nabi Muhammad SAW. ${ }^{7}$ Terlebih lagi,

Secara tradisional, seseorang yang menyandang gelar "sayyid" diyakini merpakan keturunan nabi Muhammad SAW. Oleh karena itu, status sosialnya dianggap lebih tinggi dan lebih terhormat ketimbang orang ataupun keluarga Arab yang lainnya. Terkait label tersebut, tingkat kekhususannya bisa dilihat dari keyakinan apabila seorang "syarifah" (sharīfah - wanita yang dipercayai sebagai keturunan nabi) ingin agar gelarnya tetap ada maka ia harus menikahi seorang "sayyid". Lihat, Zulkifli, The Struggle of the Shi 'is in Indonesia, (Canberra: ANU E Press, 2013), hlm. 221. Dengan bersandar pada kajian Azra, ia juga menyatakan bahwa Sayyid Usman menolak keras pernikahan antara seorang keturunan 
ulama yang masa kecilnya dihabiskan di tengah lingkungan keluarga Arab di Pekojan itu, memang dibesarkan oleh kakeknya yang merupakan seorang syekh terkemuka pada zamannya. Di tangan ayah ibunya itu Sayyid Usman kecil mendapat pendidikannya yang pertama.

Berkat garis genealogisnya yang terhubung dengan sosok-sosok kharismatik tersebut, sejak kecil Sayyid Usman telah dianggap istimewa oleh banyak kalangan Islam, terutama kelompok keluarga Arab yang memang hampir selalu memandang derajat sosial seseorang dari aspek-aspek keturunan dan keluarga seperti itu. Di samping itu, pengajaran wawasan dan pengetahuan Islam yang diberikan Syekh Al-Mișrī, membuat cucunya itu semakin terlihat cemerlang di tengah-tengah masyarakat Islam Batavia.

\section{Sang kakek mengajarkan} Sayyid Usman untuk membaca Quran, penguasaan bahasa Arab, ilmu fikih, pemikiran tentang teologi, ilmu hadis, tafsir, dan juga ilmu-ilmu keislaman lainnya. Di samping itu, Syekh Al-Mișrī juga acapkali mengajak Sayyid Usman kecil untuk mengikuti pelbagai macam kegiatan yang dijalaninya, mulai dari berkeliling untuk menghadiri undangan kajian dan dakwah Islam hingga datang ke tempat Gubernur Jenderal di Batavia untuk mendiskusikan persoalanpersoalan yang berkaitan dengan Islam di tengah masyarakat Hindia Belanda pada saat itu.

Pada tahun 1847, Syeikh alMișrī menghembuskan nafas terakhirnya. Ia meninggalkan Sayyid Usman yang di waktu itu masih berusia 18 tahun. Merasa bahwa ia harus mengembangkan diri dan tidak larut dalam kepedihan akibat ditinggalkan oleh mentor terbaiknya, Sayyid Usman pun berangkat ke tanah Arab untuk melanjutkan studinya. $^{8}$ Di samping untuk mengaktualisasikan diri dan jiwanya, kepergiannya ke tanah Timur Tengah adalah untuk menemui ayah dan juga saudara-saudaranya yang telah terpisah selama lebih dari satu dekade sejak usianya masih kecil di tanah Betawi.

Sejumlah ulama terkemuka di abad ke-19 yang ada di jazirah Arab didatangi oleh Sayyid Usman, seperti Syaikh Aḥmad Zayni Dạ̣lān (seorang mufti Madzhab Syafi'i di hlm. 10 . 
Makkah) ${ }^{9}$, Syaikh Aḥmad alDimyāṭ̂̄, dan Sayyid al-Ḥabīb Muhammad ibn Ḥusayn al- Habshī. ${ }^{10}$ Tidak hanya itu, ia juga melakukan perjalanan ke tempat-tempat lain yang ada di tanah Arab untuk semakin memantapkan khazanah keilmuannya. Sejumlah tempat itu antara lain adalah Mekkah, Madinah, Hadramaut, Mesir, Tunisia, Maghribi, Aljazair, Fes, Istanbul, Palestina, dan Suriah. ${ }^{11}$

Dari keseluruhan perjalanan Sayyid Usman untuk memantapkan ilmunya ke Timur Tengah, Afrika Utara dan gerbang Asia serta Eropa di Istanbul, perjalanan yang menjadi titik vital dan sangat penting bagi pemikirannya adalah kunjungannya ke negeri nenek moyangnya di Hadramaut, sebuah lembah yang cukup subur di wilayah Yaman sekarang. Bertahun-tahun lamanya Sayyid Usman mukim di Hadramaut bersama keluarga besarnya, antara

9 Abdullah bin Usman, Suluh Zaman, (Jakarta: Percetakan Sayyid Usman, tt), hlm. 3.

10 Sayyid Usman, Dzikru Masyaikh al-Mu'allif, (Manuskrip), hlm.. 1.

11 Henri Chambert-Loir, dkk., "Kitab Manasik Haji dan Umrah yang Pertama dalam Bahasa Melayu: Sayyid Uthman, 1875," dalam Henri Chambert-Loir, dkk., Naik Haji di Masa Silam: Kisah-Kisah Orang Indonesia Naik Haji 14821890, (Jakarta: Kepustakaan Populer Gramedia, 2013), hlm. 936. Bandingkan pula dengan tulisan sang anak yang turut memperinci proses perjalanan akademis sang ayah dalam, Abdullah bin Usman, Suluh Zaman ...., hlm. 5-6. tahun 1847-1862. Di wilayah yang dekat dengan Samudera Hindia itu, Sayyid Usman datang ke para ulama yang masyhur untuk memperdalam ilmunya. Pada saat masa studi di Hadramaut inilah, yang menjadi fase penting bagi pembentukan karakter dan pemikiran sang sayyid asal Betawi.

\section{Sayyid Usman belajar} mengenai implementasi unsur-unsur syariah di dalam kehidupan kepada Syeikh 'Abdullāh ibn Țāhir. Dalam catatan historis, ia dikenal sebagai sosok guru yang menekankan urgensinya penerapan syariah di dalam aktivitas sehari-hari. Implementasi yang dilakukan pun mesti dibarengi dengan penolakan terhadap pelestarian adat-istiadat lokal yang dianggap tidak sejalan dengan syariat Islam. Selain kepada Syeikh ibn Țāhir, Sayyid Usman juga datang dan banyak belajar dari 'Abdullāh ibn 'Umar ibn Yaḥyā. Dari gurunya yang satu ini, Sayyid Usman banyak belajar tentang pelbagai fatwa ulama tentang isu-isu keagamaan. Himpunan fatwa yang berasal dari Syeikh 'Abdullāh ini pula yang di kemudian hari menjadi salah satu acuan Sayyid Usman dalam mengurusi masalah-masalah yang berkaitan dengan masyarakat Islam di Hindia Belanda. Selain sibuk dengan aktivitas menuntut ilmunya kepada ulama-ulama 
terkenal di bagian selatan jazirah Arab itu, ia juga dikabarkan pernah menikah dengan seorang gadis "sharîfah" yang berasal dari keluarga besar Ibn Sahl disana. ${ }^{12}$

Setelah sekian lama tinggal di Hadramaut guna membekali diri dengan ilmu dan wawasan yang luas, Sayyid Usman akhirnya merasa rindu akan tanah kelahirannya sehingga kemudian kembali ke Batavia pada tahun 1862. Disana ia pulang kembali ke keluarganya, keluarga besar Syekh Al-Mișrī di kampung Arab yang telah puluhan tahun ia tinggalkan.

Pada mulanya, di kampung halamannya itu, Sayyid Usman tidak banyak melakukan aktivitas, baik itu yang bersifat sosial ataupun keagamaan. Saat itu, ia hanya menjadi seorang guru ngaji di sebuah masjid yang berada di dalam lingkungan kampung Arab yang didiaminya. Setelah itu, Haji 'Abd al-Ghanī Bima yang menjadi imam di masjid Pekojan, seringkali absen memimpin ibadah karena alasan kesehatan. Ulama Jawi yang juga berguru di Mekkah dan masyhur

12 Lihat, Muhammad Noupal, Pemikiran keagamaan Sayyid Usman bin Yahya (18221914): Respon dan Kritik Terhadap Kondisi Sosial Keagamaan di Indonesia, Disertasi tidak diterbitkan, (Jakarta: Sekolah Pascasarjana Universitas Islam Negeri (UIN) Syarif Hidayatullah, 2008). pada akhir abad ke-19 itu sudah mulai sakit-sakitan karena alasan usia. Sayyid Usman pun diminta untuk menggantikannya ketika ia tidak lagi intens untuk datang ke masjid Pekojan.

Melalui peran barunya di masjid yang berada di kampung Arab yang mulanya banyak ditempati kelompok India muslim itu, nama Sayyid Usman pun semakin dikenal. Pengajian yang awalnya hanya dihadiri oleh beberapa orang saja, berubah drastis karena jumlahnya meningkat menjadi pengajian besar yang para pendengarnya datang dari banyak tempat di wilayah dalam dan luar kawasan Batavia. Sejumlah murid Sayyid Usman yang terkenal antara lain Habib Ali al-Habsyi Kwitang, Habib Umar Purwakarta dan Habib Falakiyyah Bogor. Selain itu, banyak pula muridnya yang berasal dari luar seperti Surabaya dan Banjarmasin.

Dengan besarnya jamaah yang dimiliki, maka sontak nama Sayyid Usman pun semakin melejit sebagai sosok ulama penting di tengah masyarakat. Pamor tersebut kemudian membuat Haji 'Abd alMu'īn datang ke Pekojan dan meminta Sayyid Usman untuk menjadi salah satu pengajar di masjid Pasar Senen yang terletak di wilayah Kampung Besar. 
Dengan perannya sebagai ulama itulah ia acapkali dimintai saran dan pandangannya tentang masalah keagamaan oleh kalangan luas. Agar lebih mudah dan praktis dalam menyampaikan serta menyebarluaskan gagasan-gagasan keagamaannya, ia pun mulai menulis risalah-risalah. Dengan catatan yang dibuatnya itu, masyarakat lebih mudah melihat pandangan Sayyid Usman terkait masalah-masalah keagamaan yang dihadapi oleh masyarakat. Karena tulisan-tulisan risalahnya itu berjumlah terbatas dan tidak dapat menyebar luas, maka Sayyid Usman pun memiliki gagasan untuk mencetak karya-karyanya. Kondisi itu pun kemudian memaksanya untuk memulai babak baru dalam kehidupan intelektualnya dengan melakukan gebrakan perintisan teknologi percetakan di dalam membumikan karya-karyanya. Dengan upayanya tersebut, banyak kalangan yang menganggap Sayyid Usman sebagai salah satu pelopor bagi perkembangan teknik litografi di Indonesia. ${ }^{13}$

13 Penyebutan itu dapat dimaklumi, mengingat Sayyid Usman memang termasuk salah seorang yang paling awal berkiprah di dalam dunia percetakan Islam di Hindia Belanda. Sebelum itu, tidak ada kalangan swasta yang mencetak karyanya sendiri karena pelbagai buku terkait keislaman yang ada sebelumnya berada di bawah pengawasan pemerintah jajahan dan kelompok-kelompok organisasi misionaris Kristiani. Baca, Henri Chambert-Loir, dkk.,
Tidak dapat dipungkiri, upayanya untuk mengembangkan teknologi litografi itu telah menghantarkannya menjadi sosok yang sangat dikenal pada masa itu karena dengan hasil cetak yang banyak karya-karyanya itu dapat menyebar luas dan menjangkau hingga kalangan-kalangan tertentu di wilayah pedesaan dan pedalaman daerah. Dengan demikian, penggunaan teknologi tersebut memiliki pengaruh yang sangat signifikan di dalam perkembangan karir Sayyid Usman sebagai seorang ulama di abad ke-19.

Ide dan gagasan tentang Islam dan juga banyak persoalan kemasyarakatan lainnya, Sayyid Usman tuangkan di dalam karya yang digandakan dengan teknologi cetak yang dirintisnya itu. Berkat terobosan itu, Sayyid Usman menjadi sangat tersohor karena tulisannya bisa tersebar dan dapat dibaca oleh kalangan masyarakat yang luas, dari tingkat terendah hingga kalangan yang tertinggi. Pejabat-pejabat pemerintah kolonial pun turut menjadi pasar sehingga menjadi para pembaca karyanya, yang telah dicetak dan beredar sebanyak 38 karya. Dengan intensitas kesibukan yang sangat

Naik Haji di Masa Silam: Kisah-Kisah Orang Indonesia Naik Haji 1482-1890, (Jakarta: Kepustakaan Populer Gramedia, 2013). 
padat, akhirnya bisnis percetakan itu pun menjadi kegiatan utama Sayyid Usman dan sosok ulama tersebut sedikit demi sedikit meninggalkan aktivitasnya sebagai seorang pengajar di masjid. ${ }^{14}$

Di saat pamornya itu sedang meroket tinggi, ternyata banyak pihak yang memerhatikan prestasi yang diraihnya. Ketika tokoh itu diperhatikan lebih seksama, pemerintah kolonial melihat ada potensi lain di dalam diri Sayyid Usman yang bisa mereka manfaatkan untuk kepentingan dari kelanjutan masa kekuasaan mereka di tanah Hindia. Pada akhirnya, pemuka agama Islam Hadrami itu pun diangkat sebagai Adviseur Honorair voor Arabische Zaken (Penasehat Kehormatan untuk Urusan bangsa Arab). Ia duduk di kursi empuk struktur administrasi kolonial, bersama-sama dengan Christian Snouck Hurgronje yang masyhur sebagai pengkaji Islam Indonesia sekaligus penasehat pemerintah mengenai kebijakan-kebijakan yang berkaitan dengan umat Islam.

Setelah sekian tahun berkarya, Sayyid Usman menghembuskan nafas terakhirnya pada malam Senin

${ }^{14}$ Nico Jan Gerrit Kaptein, Islam, Colonialism, and the Modern Age in the Netherlands East Indies: A Biography of Sayyid 'Uthman (18221914), (Leiden \& Boston: Brill, 2014), hlm. 77.
12 Shafar atau 19 Januari 1914. Pada saat itu, usianya telah mencapai angka 92 tahun. Sosok kharismatik itu dikuburkan di pemakaman rakyat Tanah Abang dengan iringan dan tangisan para muridnya yang kurang lebih berjumlah sekitar 10.000 orang. Meskipun pemakaman itu sangat bernilai historis, nyatanya kini areal tersebut sudah tidak ada dan sebagian peninggalan-peninggalan yang dianggap berharga dari sana pun telah dipindahkan ke Museum Prasasti. ${ }^{15}$

Pendiriannya sebagai seorang pembaharu pun tetap teguh, bahkan ketika ia meninggal. Seluruh keturunannya tidak ia perkenankan untuk melakukan haul atau peringatan tentang kematian dirinya. Hal itu sengaja dilakukan karena memang Sayyid Usman secara konsisten selalu menolak segala hal yang ia anggap sebagai bid'ah dan tarekat yang menurutnya sangat bertentangan dengan syariat agama Islam. Melalui cara pandang itulah maka tidak mengherankan apabila kemudian Steenbrink menyebutnya

15 Muhammad Noupal, "Kontroversi Tentang Sayyid Utsman Bin Yahya (1822-1914) Sebagai Penasehat Snouck Hurgronje" dalam Conference Proceedings: Annual International Conference on Islamic Studies (AICIS XII), 5-8 November 2012, Surabaya - Indonesia, hlm. 1374. 
sebagai salah seorang ulama yang paling berpengaruh di abad ke-19. ${ }^{16}$

Konsistensi sikap antipati Sayyid Usman terhadap pelbagai macam penyimpangan dalam agama, juga dibuktikan oleh pesan terakhirnya sebelum wafat. Dalam kesempatan itu, ia berkata:

"Pesan Sayyid Utsman berbunyi, "Berhati-hatilah kalian. Nanti setelah wafatku, pasti akan banyak lagi fitnah dan penyimpangan dalam agama seperti yang pernah dikatakan oleh Nabi bahwa nanti di akhir zaman akan timbul segala macam fitnah, semakin akhir akan semakin berlebih-lebihan. Nanti akan keluar banyak Dajjal selain dari Dajjal yang matanya juling. Mereka akan membuat Islam menjadi rusak, menghalalkan barang yang haram dan mengharamkan barang yang halal. Maka jika kamu mendapati mereka janganlah sekali-kali kamu menghampirinya, dan janganlah sekali-kali kalian mendengar segala perkataan dan bujuk rayu mereka. Karena mereka sangat pandai

16 Baca, Karel A. Steenbrink, Beberapa Aspek Tentang Islam di Indonesia, (Jakarta: Bulan Bintang, 1984). membuat orang menjadi hancur. Jangan kamu hiraukan mereka. Jauhi mereka". 17

Ketika meninggal, Sayyid Utsman meninggalkan 8 orang putra dan 5 orang putri. $^{18}$ Meskipun jumlah seluruh keturunannya itu bisa dikatakan sangat banyak, ternyata di antara mereka tidak ada yang memiliki tingkat kemahiran seperti halnya kompetensi Sayyid Usman di dalam menulis sebuah karya dan mengelola usaha penerbitan. ${ }^{19}$

\section{Menjadi Pegawai Hindia Belanda}

Pengangkatan Sayyid Usman oleh penguasa Batavia sebagai orang penting di kursi jajaran kekuasaan kolonial tidak terjadi secara tiba-tiba ataupun dalam waktu yang singkat, karena ada sejumlah proses yang terlebih dahulu mengawalinya.

Hal itu dimulai ketika namanya mencuat sebagai salah seorang ulama yang memiliki pengaruh akibat karangannya yang telah menyebar luas di tengah masyarakat banyak

17 Abdullah bin Utsman, Suluh Zaman ...., h. 17-18.

18 Beberapa putra Sayyid Usman tersebut antara lain adalah 'Aqil, 'Alwi, Hasan, Muhammad, Hamid, Husein, Abdurrahman dan Yahya; dan beberapa anak perempuannya adalah Khadijah, Sida, 'Alwiyyah, Nur dan Muhani

19 Abdul Aziz, Islam dan Masyarakat Betawi, (Jakarta: Logos, 2002), h. 61. 
diterima dan menjadi rujukan untuk penentuan pandangan hukum di dalam kehidupan masyarakat Islam Nusantara. Signifikansi sosoknya sebagai ulama itu dapat jelas terlihat terutama karena keramaian jamaah yang luar biasa ketika ia mengadakan pengajian-pengajian di masjid-masjid yang dipercayakan kepadanya seperti masjid Pekojan. Berduyun-duyun orang datang ke tempat itu, hanya demi mendengarkan sajian dan paparan ilmu pengetahuan yang disajikan oleh sang mufti Betawi.

Selain untuk mereguk ilmu dan mendengarkan curahan ilmu agama yang disajikannya, masyarakat yang datang juga terkadang sengaja hadir disana untuk maksud-maksud lain yang masih relevan dengan konteks keislaman. Dengan citranya yang telah meningkat itu, Sayyid Usman menjadi sosok yang amat dihormati. Tidak hanya oleh masyarakat Islam pribumi dan juga keturunan Arab yang ada, namun juga oleh kalangan Eropa yang tinggal di Batavia. ${ }^{20}$

Bagaimana orang-orang kulit putih Eropa bisa sampai menghormati sosok Sayyid Usman di Batavia? Hal itu dimulai ketika seorang penasehat pemerintah

20 Christian Snouck Hurgronje, "Islam dan Fonografi”, dalam Kumpulan Karangan Snouck Hurgronje IV, (Jakarta, INIS, 1992), hlm. 175.
Hindia Belanda bernama K.F. Holle meminta Sayyid Usman untuk menggambarkan peta negeri leluhurnya, yaitu Hadramaut. Sang sayyid pun ternyata menjawab permintaan itu dengan sempurna sehingga membuat pejabat kolonial itu terkesima. Sontak saja, akibat kejadian itu namanya langsung melejit di tengah perbincangan kaum kelas atas ibukota tanah koloni Belanda.

Peristiwa itu secara tidak langsung juga menunjukkan bahwa Sayyid Usman merupakan orang yang memiliki pergaulan luas. Interaksi dan relasi sosial yang dibangunnya pun tidak sebatas kelompoknya saja, namun menjangkau masyarakat luas hingga ke pihak-pihak yang dianggap sebagai kelompok "kafir" sekalipun seperti masyarakat Eropa. Pandangan itu banyak dipengaruhi oleh ajaran sang kakek, Syeikh Al Misri, yang senantiasa mengajarkannya sejak saat kecil untuk selalu terbuka kepada dunia. Bahkan, Sayyid Usman kecil seringkali diajak bepergian oleh sang kakek ke tempat Gubernur Jenderal Hindia Belanda, Pieter Merkus, yang menjabat dari tahun 1841-1844. Di rumah besar yang lebih mirip dengan istana itu, sang mufti kecil melihat bagaimana penguasa tertinggi kolonial meminta saran, pendapat, dan nasehat dari 
sang kakek yang seorang ulama. Uraian ini diperkuat oleh catatan L.W.C. van den Berg, sarjana Belanda ahli Arab di Hindia Belanda, yang menyatakan bahwa alMișrī memiliki hubungan yang cukup dekat dengan para pejabat tinggi pemerintah kolonial Belanda pada masa penjajahan. ${ }^{21}$ Pengalaman di masa kecil itu terpatri di dalam diri dan kemungkinan secara tidak langsung menjadi pendorong alamiah sang sayyid untuk tidak bersikap antipati kepada para penguasa dan pejabat teras pemerintahan kolonial.

Sosok Sayyid Usman semakin dihormati karena memiliki banyak karya yang dicetak oleh perusahaan penerbitannya sendiri untuk memberi penjelasan wawasannya guna melawan praktik-praktik bid'ah dan khurafat serta gerakan tarekat Islam yang masih banyak dijalani dan malah berkembang oleh masyarakat pada masa itu. Puluhan karya berhasil ditelurkan untuk mewujudkan upayanya tersebut. Pemerintah kolonial yang memiliki masalah akan gerakan-gerakan tarekat yang menjadi motor perlawanan masyarakat Islam pribumi, tidak ingin kehilangan

21 Jajat Burhanudin, "Islam dan Kolonialisme: Sayyid Usman dan Islam di Indonesia Masa Penjajahan", Book Review dalam Studia Islamika, Vol. 22, No. I., 2015. momentum. Maka dengan cekatan, mereka pun meminta sang mufti untuk bergabung sebagai pegawai kolonial dan akhirnya hal itu diamininya. Pada bulan April 1891, Sayyid Usman diangkat secara terhormat sebagai penasehat pemerintah Belanda. $^{22}$

Walaupun begitu, Sayyid Usman sendiri tidak pernah mengakui secara langsung di depan para jamaahnya bahwa ia adalah seorang penasehat pemerintah kolonial yang mengurusi pelbagai persoalan yang berkaitan dengan masyarakat Arab di Nusantara. Informasi tersebut justru baru terkuak dari lembaran-lembaran surat dan nasihat rahasia Christian Snouck Hurgronje yang baru diterbitkan setelah era kemerdekaan Indonesia. Dalam terbitan-terbitan tersebut, diketahui bahwa Hurgronje telah membicarakan sosok Sayyid Usman sejak kedatangannya di tahun 1889. Bahkan di tahun itu, ia telah membicarakan secara khusus posisi yang telah disiapkan untuk Sayyid Usman kepada Gubernur Jenderal Hindia Belanda yang tengah berkuasa, Cornelis Pijnacker Hordijk. $^{23}$

22 Muhammad Noupal, "Kontroversi Tentang ...., hlm. 1739.

23 E. Gobee dan C. Adriaanse, NasehatNasehat Snouck Hurgronje Semasa Kepegawaiannya kepada Pemerintah Hindia 
Kejelasan mengenai status Sayyid Usman di dalam struktur pemerintahan kolonial, dapat dilihat dari surat usulan lain Snouck Hurgronje yang ditujukan kepada directeur van Onderwijs, Eeredienst en Nijverheid (Direktur Pengajaran, Ibadah, dan Kerajinan) Hindia Belanda. Dalam surat bertanggal 5 April 1891 itu, disebutkan pelbagai manfaat karya-karya yang diterbitkan Sayyid Usman bagi pemerintahan kolonial dan usulan pengangkatannya.

Dalam suratnya itu, Snouck Hurgronje menuliskan:

"Mengingat banyak sekali hasil karyanya, maka pengakuan memberi salah satu penghargaan dari pemerintah, menurut penglihatan saya, Sayyid Usman justru berhak atas hal itu."

Dalam kelanjutannya pada bagian akhir surat, ia mengatakan:

"Barangkali saya perlu memberanikan diri untuk memberi pertimbangan kepada paduka Tuan, sudilah mengusulkan kepada pemerintah pusat untuk mengangkat Sayyid Usman bin Abdullah bin Aqil bin Yahya

Belanda 1889-1936, Seri Khusus INIS IX. (Jakarta: INIS, 1990), hlm. 1623.
'Alawi sebagai Penasehat Kehormatan untuk urusan Bangsa Arab". ${ }^{24}$

Sebagai kompensasi atas posisinya itu, Sayyid Usman pun mendapat sejumlah uang setiap bulannya. Bahkan dikabarkan bahwa di samping "gaji" bulanan yang diterimanya atas informasi dan nasehat yang ia berikan kepada pemerintah kolonial mengenai perkembangan Islam Hindia Belanda, ia juga diduga diberi sejumlah uang untuk pemeliharaan dan pengembangan usaha penerbitannya. Pelbagai karya yang lahir dari situ, dianggap pejabat kolonial saat itu cocok sebagai alat untuk memelihara status quo politik Hindia Belanda. ${ }^{25}$

Di samping kedudukan yang prestisius, pemerintah kolonial juga menganugerahi Sayyid Usman sejumlah penghargaan lain yang bersifat resmi, yaitu medali Bintang Mas (Golden Star) dan medali Singa Belanda (Nederlanschen Leeuw). Dasar penganugerahan itu adalah usaha untuk melindungi masyarakat dari berbagai bentuk bid'ah yang

24 E. Gobee dan C. Adriaanse, NasehatNasehat Snouck Hurgronje Semasa Kepegawaiannya kepada Pemerintah Hindia Belanda 1889-1936, Seri Khusus INIS IX. (Jakarta: INIS, 1990), hlm. 1626.

25 Karel A. Steenbrink, Beberapa Aspek Tentang Islam ...., hlm. 15. 
tampaknya telah menjadi prinsip yang dipegang teguh oleh Sayyid Utsman di dalam hidupnya. ${ }^{26}$

\section{Pandangan Sayyid Usman tentang Pemerintah Kolonial Hindia Belanda}

Untuk memahami pemikiran dan pandangan Sayyid Usman secara mendalam, maka salah satu cara yang bisa digunakan adalah dengan memahami keseluruhan karya-karya yang telah dibuatnya. Seluruh karya yang ditulis oleh Sayyid Usman, ternyata jumlahnya lebih dari 100 buah karya. Hal itu menunjukkan bahwa sang sayyid adalah sosok yang produktif dalam mengarang dan menulis suatu buku.

Nico

Kaptein, mengelompokkan karya Sayyid Usman ke dalam dua kategori yang berlainan meskipun pada dasarnya saling berhubungan. Keduanya adalah karya yang menyangkut isu aktual dan kontroversial serta karyakarya lain yang bersifat umum. ${ }^{27}$

Kumpulan karyanya yang kontroversial itu, antara lain al-Qawl al-Sawāb dan Tawḍih al-Adillah 'alá

26 Abdullah bin Usman, Suluh Zaman ...., hlm. 17.

${ }^{27}$ Baca, Jan Gerrit Kaptein, Islam, Colonialism, and the Modern Age in the Netherlands East Indies: A Biography of Sayyid 'Uthman (18221914), (Leiden \& Boston: Brill, 2014).
Surüt Shuhūd al-Ahillah yang ditulis pada tahun 1882. Kedua buku ini berisi tentang penentuan hari pertama dalam menjalankan ibadah puasa dan idul Fitri, yang memang pada 1868 dan kemudian pada 1882 terjadi perbedaan di Batavia oleh pelbagai macam kelompok Islam saat itu. Dalam konteks tersebut, metode dan kajian penentuan awal bulan melalui metode hisab dan rukyat pada dasarnya memang berbeda.

Karangan Sayyid Usman yang banyak diperdebatkan selanjutnya adalah Șimt al-Sudur wa al-Jawāhir fi Hall Takhșiș al-Nuzur li al-Sada al-Atahir, yang membahas mengenai harta peziarah makam Habīi Husayn ibn Abī Bakr ibn 'Abdillāh al'Aydrūs, seorang ulama terkenal yang wafat pada tahun 1756 di Luar Batang, Batavia. Jika ulama setempat menyebut harta itu sebagai hak untuk pemerintah lokal, maka Sayyid Usman memberikan fatwa bahwa harta yang diberikan para peziarah disana adalah hak yang mesti dimiliki oleh keluarga Habīb Husayn. Pendapat Sayyid Usman ini didukung oleh fatwa yang dikeluarkan mufti Mekkah, Syaikh Aḥmad Dahlān, yang tidak lain merupakan guru dari sang mufti Betawi sendiri. Dengan penguatan tersebut, maka tidak mengherankan apabila kemudian fatwa Sayyid 
Usman dianggap sangat otoritatif terkait pembahasan persoalan mengenai makam keramat tersebut.

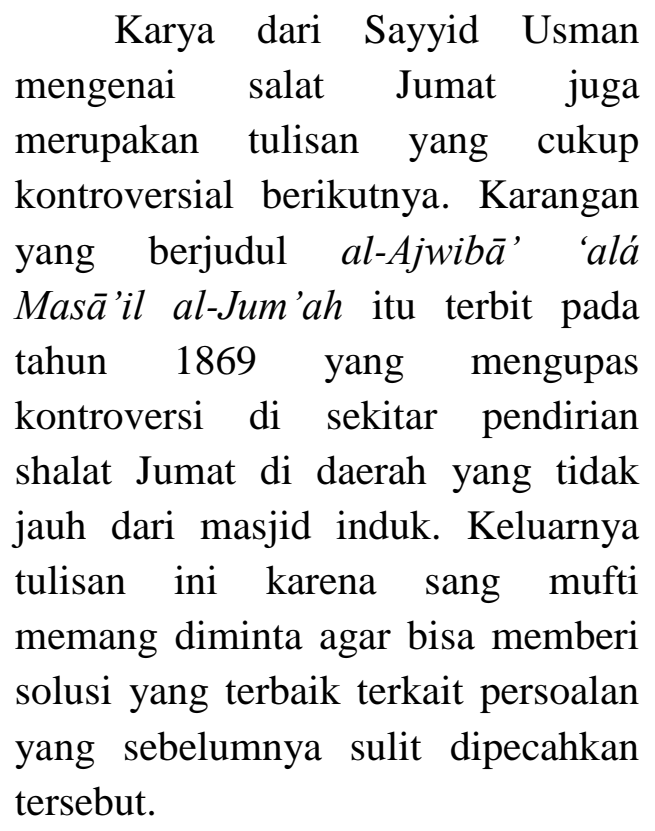

Sedangkan untuk kategori lainnya, Sayyid Usman juga menulis sejumlah karya yang jumlahnya tidak sedikit. Karangan-karangan yang memuat ajaran Islam dan kaum Muslim secara umum itu, beberapa di antaranya adalah Kitab Sifat Dua Puluh (1886) yang berisi tentang teologi, lalu ada pula Kitab Manasik Haji dan 'Umrah, dan karya lain tentang pentingnya berperilaku sesuai ajaran Islam, al-Tuffahă' alWardīyah min Riyāẹ al-Sharīfah alMuhammadīyah fì al-Nașīhah alMurdīyah (1880). Selain itu, tercatat kitab berjudul Ini Kitab Menyatakan Perihal Junjunan Kita Sayyidinā wa Mawlānā Muhammad (1881), yang merupakan karya sang mufi yang menguraikan tentang nabi Muhammad. Lalu yang tidak kalah menariknya, adalah karya-karya lain yang berjudul Risalah Ada Di Dalamnya Hadis Keluarga (1886) yang berisi geneologi keluarga kelompok sayyid, Kitab 'Ilm alFarā'id (1884) tentang cara pembagian harta waris, dan Adāb alInșān (1885) yang berisi pedoman tentang perilaku yang baik sesuai ajaran Islam. Di samping itu, Sayyid Usman juga membuat sebuah karya yang di kemudian hari membuatnya menjadi seorang ulama yang dikenal pejabat kolonial, yaitu kitab yang berisi atlas Hadramaut dan diterbitkan pada tahun 1883 .

Meskipun cakupan materi karya-karya yang dibuatnya itu sangat bervariasi, mulai dari hal yang berkaitan dengan ide dan gagasan pembaruan Islam hingga ke tata cara yang cukup detail dalam melakukan proses manasik haji, namun sejumlah karya memang menunjukkan kecenderungan sikap dan pandangannya tentang kekuasaan administrasi kolonial di Nusantara. Kecenderungan itu dapat terlihat dari karya-karyanya yang membahas tentang gerakan dan perkembangan pembaruan Islam. Semua tulisan itu, hanya berjumlah sekitar 7 (tujuh) buku dan telah ditulis pada awal 
abad ke-20. ${ }^{28}$ Buku-buku ini adalah buku yang secara eksplisit mengkritisi pelbagai penyimpangan dalam Islam dan juga gerakangerakan tarekat serta pesantren di dalamnya. Meskipun demikian, tulisannya tidak langsung tertuju kepada Islam Indonesia dan secara normatif ia katakan sebagai tulisan yang ditujukan kepada gerakan gerakan pembaharuan Islam secara umum di dunia ini. Oleh karena itu, ketujuh buku itu bukanlah buku yang secara khusus membahas perihal Islam dalam konteks Indonesia melainkan risalah yang menguraikan gerakan pembaharuan Islam yang menurutnya harus suci dan jernih sesuai dengan ajaran nabi, tidak dicampuri oleh unsur-unsur lokal yang menurutnya merusak kesucian ajaran Islam.

Daftar karya sang syaikh yang berhubungan dengan ide-ide pembaharuan dan berjumlah sekitar tujuh buku itu, empat di antaranya ditulis oleh Sayyid Usman pada tahun 1911, dan dua di antaranya ditulis sebelumnya yaitu pada tahun 1905 dan 1909. Secara lengkap, buku-buku karya Sayyid Usman yang dimaksud yang khusus

28 M. Noupal, "Kritik Sayyid Utsman bin Yahya Terhadap Gerakan Pembaharuan Islam di Indonesia : Studi Sejarah Islam di Indonesia Abad 19 dan Awal Abad 20", dalam JIA (Desember 2013, Th.XIV, No. 2), hlm. 79-80. mengenai ide-ide pembaharuan adalah Tarîq al-Salâmah $\min$ alKhusrân wa al-Nadâmah (1911); Salâmat al-Muslimîn min al-Ibtidâ' fî al-Dîn (1911); Fasl al-Khitâb fî̀ Bayân al-Sawâb (1911); I'ânat alMustarsyidîn 'alâ Ijtinâb al-Bida' fì al-Dîn (1911); 'Ainu al-Haqq wa Faslu al-Khitâb (1905); Jam'u alNafầ is li Tahsîn al-Madâris (1909); dan al-Haqq al-ladzî Yajibu Ittibâ'uhu fí al-Dîn (tt). ${ }^{29}$ Karya yang disebutkan terakhir inilah yang memuat informasi lengkap dari Nabhani, sekalipun tidak diketahui secara pasti tahun berapa karangan ini disusun.

Dengan daftar karya yang tidak sedikit itu, tentunya kita dapat memahami bahwa posisi penting Sayyid Usman dalam masalah keagamaan di masa kolonial memang tidak terbantahkan.

Pemikiran Sayyid Usman tentang Islam dan Kaum Muslim yang secara umum bersifat lurus ternyata dapat dimanfaatkan oleh pihak kolonial untuk menekan gejala-gejala sosial keagamaan yang mereka takutkan. Melalui pemanfaatan itu pula pada akhirnya membuat pemikiran seorang Sayyid Usman seakan cenderung bersifat pragmatis dan politis.

29 M. Noupal, "Kritik Sayyid Utsman ...., hlm. 81. 
Sebagai contoh, al-Nașīhah al'Anīqah li al-Mutalabbisin bi alTarīqah, kitab karya Sayyid Usman yang diterbitkan tahun 1883 di Batavia, ternyata menjadi pegangan pihak kolonial dalam menetralisir gerakan keagamaan tarekat di wilayah Cianjur. Dengan berdasarkan kepada kitab ini, penasehat urusan pribumi di Jawa Barat, K.F. Holle, bisa menetralisir gerakan tarekat di Cianjur dengan mengemukakan gerakan tersebut sebagai upaya keagamaan yang memiliki potensi untuk membahayakan Hindia Belanda. Pejabat di Batavia pun mulai mencoba melakukan pendekatan kepada sang mufti Betawi. Mengetahui bahwa dirinya dilirik oleh pihak penguasa, Sayyid Usman pun mengirimkan sinyal-sinyal persahabatan. Hingga kemudian hubungan itu berubah amat hangat karena diterima dengan tangan terbuka oleh seorang penasehat penting urusan agama orang pribumi Hindia Belanda, Christian Snouck Hurgronje, yang usianya jauh lebih muda dari Sayyid Usman.

Orientasi pemikiran cucu Syaikh al Misri untuk dekat dengan pihak kolonial juga terekam jelas dalam catatan-catatan kolonial yang menyebutkan bahwa Sayyid Usman merupakan ulama yang bersedia untuk membuat sebuah doa spesial untuk Ratu Belanda Wilhelmina yang akan segera naik tahta, yang akan dibacakan di dalam seremoni upacara naiknya sang ratu ke singgasana pada 31 Agustus 1898. Aktivitas itu dikritik banyak pihak, bahkan termasuk oleh kalangan Arab dan keturunan Arab sendiri, karena di dalam untaian do'a yang dituliskan terdapat kata-kata pujian untuk Ratu Wilhelmina dan pihak kolonial Belanda. Bahkan doa tersebut diperbanyak dan dibagibagikan kepada khalayak luas. ${ }^{30}$

Melalui doa kontroversial yang ditulisnya itu, akhirnya pada 31 Agustus 1899 Sayyid Usman dianugerahi pemerintah kolonial sebagai anggota Orde of the Netherlands Lion (Rezim Penguasa Belanda).

${ }^{30}$ Mengenai sikap kontroversialnya, Steenbrink menulis bahwa Sayyid Usman bermuka dua: meski memperjuangkan kemurnian ajaran Islam, ia juga mendukung pemerintah kolonial. Terkait hal itu, sikap yang saling bertolak belakangnya tersebut dapat juga dilihat dari peristiwa pembacaan doa oleh sang mufti: dimana ia pernah menolak untuk memimpin membaca doa di dalam sebuah acara yang dihelat oleh seorang Arab di Batavia karena di tempat itu terdapat gambar Ratu Wilhelmina, padahal di hari ulang tahun sang Ratu Belanda di tahun 1898 ia menyusun doa khusus untuk kesejahteraan dan keselamatan Ratu Wilhelmina. Lihat, Nico Jan Gerrit Kaptein, "The Sayyid and The Queen: Sayyid Uthman on Queen Wilhelmina's Inauguration on the Throne of the Netherlands in 1898", dalam Journal of Islamic Studies (tk, tp, 1998). 
Bagi kelompok Muslim di Indonesia, barang tentu sikap Sayyid Usman yang memberi dukungan terhadap pelbagai kebijakan pemerintahan Hindia Belanda itu dianggap sebagai sebuah kesalahan. Mengingat, jalan yang ditempuhnya itu menjadikan sang sayyid sebagai penyerang aktif nan agresif kalangan ulama pesantren dan pendukung tarekat. Cara yang demikian itu, tentu tidak dapat diterima.

Kaum penguasa kulit putih, bukan hanya bertindak sebagai penindas dan penjajah, melainkan juga berperan sebagai orang yang kafir dan tentunya anti-Islam. Oleh karena itu, adalah suatu keanehan apabila ada oknum dari kaum Muslim, terlebih seorang ulama besar, yang malah memberi dukungan kepada mereka yang seharusnya menjadi musuh abadi umat Muslim tersebut.

Pada dasarnya, posisi mufti di masa kolonial memang tidak jauh berbeda dengan posisi seorang penghulu. Karena yang mengangkat adalah pejabat pemerintah, maka secara tidak langsung mereka merupakan bagian dari kolonialisme. Tidak hanya mufti, penghulu pun acapkali mendapat perlakuan dan citra yang kurang baik dari umat Muslim kebanyakan. ${ }^{31}$

\section{E. Penutup}

Sayyid Usman merupakan tokoh penting Islam yang sangat masyhur di akhir abad ke-19 dan awal abad ke-20. Namanya mencuat ke permukaan akibat gebrakannya dalam menyebarluaskan karya-karya Islam melalui teknologi litografi percetakan. Puluhan karya berhasil ditelurkan oleh ulama yang puluhan tahun telah menuntut ilmu kepada syaikh-syaikh yang berada di wilayah Timur Tengah tersebut. Pengalaman kecilnya bersama sang kakek yang cukup dekat dengan orang Eropa, membuatnya tidak canggung untuk bersosialisasi dengan mereka.

Popularitas Sayyid Usman yang sangat tinggi di tengah masyarakat yang dibarengi dengan kemampuannya yang memang mumpuni, kemudian membuat pejabat-pejabat teras kolonial Hindia Belanda memberikan rekomendasi agar Sayyid Usman diangkat sebagai bagian dari mereka. Hal itu pun terjadi ketika pada akhirnya ia didapuk sebagai Adviseur Honorair

31 Muhamad Hisyam, Caught between Three Fires: The Javanese Pangulu under the Dutch Colonial Administration, 1882-1942, (Jakarta: INIS, 2001). 
voor Arabische Zaken (Penasehat Kehormatan untuk Urusan bangsa Arab). Di lembaga tersebut ia bekerjasama dengan seorang penasehat kolonial yang paling terkenal di mata publik Indonesia, Christian Snouck Hurgronje.

Pandangan Sayyid Usman terhadap gejala kolonialisme pun mendapat sorotan. Alih-alih mendukung gerakan pembaharuan Islam, sang mufti Betawi justru malah mengecam gerakan yang menjadi musuh besar kolonialisme Eropa tersebut. Meskipun ia tidak pernah secara langsung menyebutkan pembaharuan Islam yang dikecamnya berada di wilayah Nusantara, namun kritiknya jelas sekali terlihat di dalam karyakaryanya yang membahas wacana dan ide-ide pembaharuan seperti Tarîq al-Salâmah min al-Khusrân wa al-Nadâmah (1911); Salâmat alMuslimîn min al-Ibtidâ' fî al-Dîn (1911); Fasl al-Khitâb fî Bayân alSawâb (1911); I'ânat alMustarsyidîn 'alâ Ijtinâb al-Bida' fî al-Dîn (1911); 'Ainu al-Haqq wa Faslu al-Khitâb (1905); Jam'u alNafâ is li Tahsîn al-Madâris (1909); dan al-Haqq al-ladzî Yajibu Ittibâ'uhu fì al-Dîn (tt). Di samping itu, jabatannya sebagai salah seorang penasehat kolonial dan juga sejumlah aktivitasnya yang seringkali membantu pemerintah menunjukkan dengan jelas bahwa tokoh tersebut tidak pernah mencoba memberi kecaman terhadap pemerintah kolonial, dan malah seolah-olah menjaga status quo kekuasaannya. Meskipun demikian, kondisi saat itu jauh berbeda dengan konteks kekinian sehingga apa yang dilakukan sang sayyid mesti dipandang secara jernih dalam konteks ilmiah dan keilmuan.

\section{Daftar Pustaka}

Abdurahman, Dudung. 2011. Metodologi Penelitian Sejarah Islam. Yogyakarta: Ombak.

Agung, Leo. 2013. Sejarah Intelektual. Yogyakarta: Penerbit Ombak.

Aziz, Abdul. Islam dan Masyarakat Betawi. Jakarta: Logos.

Azra, Azyumardi. 1995. "Hadhrami Scholars in The MalayIndonesian Diaspora: A Preliminary Study of Sayyid Uthman" dalam Studia Islamika. Jakarta, vol. 2. No. 2.

Burhanudin, Jajat. 2015. "Islam dan Kolonialisme: Sayyid Usman dan Islam di Indonesia Masa Penjajahan", Book Review dalam Studia Islamika, Vol. 22, No. I.

Carey, Peter. 2007. The Power of Prophecy: Prince Dipanagara 
and the End of an Old Order in Java, 1785-1855. Leiden: KITLV Press.

Chambert-Loir, Henri, dkk.. 2013. "Kitab Manasik Haji dan Umrah yang Pertama dalam Bahasa Melayu: Sayyid Uthman, 1875," dalam Henri Chambert-Loir, dkk., Naik Haji di Masa Silam: Kisah-Kisah Orang Indonesia Naik Haji 1482-1890. Jakarta: Kepustakaan Populer Gramedia.

Chambert-Loir, Henri, dkk.. 2013. Naik Haji di Masa Silam: KisahKisah Orang Indonesia Naik Haji 1482-1890. Jakarta: Kepustakaan Populer Gramedia.

Ernaka, Ipik. 2007. Perlawanan Bagus Rangin di Cirebon Tahun 18061812, Tesis tidak diterbitkan. Jakarta: Program Pascasarjana Fakultas Ilmu Pengetahuan Budaya Universitas Indonesia.

Gazalba, Sidi. 1996. Pengantar Sejarah Sebagai Ilmu. Jakarta: Bhatara.

Gobee, E dan Adriaanse, C. 1990. Nasehat-Nasehat Snouck Hurgronje Semasa

Kepegawaiannya kepada Pemerintah Hindia Belanda 1889-1936, Seri Khusus INIS IX. Jakarta: INIS.

Hisyam, Muhamad. 2001. Caught between Three Fires: The Javanese Pangulu under the
Dutch Colonial Administration, 1882-1942. Jakarta: INIS.

Hurgronje, Christian Snouck. 1992. "Islam dan Fonografi", dalam Kumpulan Karangan Snouck Hurgronje IV. Jakarta, INIS.

Kaptein, Nico Jan Gerrit. 1998. "The Sayyid and The Queen: Sayyid Uthman on Queen Wilhelmina's Inauguration on the Throne of the Netherlands in 1898", dalam Journal of Islamic Studies. tk, tp.

Kaptein, Nico Jan Gerrit. 2014. Islam, Colonialism, and the Modern Age in the Netherlands East Indies: A Biography of Sayyid 'Uthman (1822-1914). Leiden \& Boston: Brill.

Noupal, Muhammad. 2008. Pemikiran keagamaan Sayyid Usman bin Yahya (1822-1914): Respon dan Kritik Terhadap Kondisi Sosial Keagamaan di Indonesia. Disertasi tidak diterbitkan. Jakarta: Sekolah Pascasarjana Universitas Islam Negeri (UIN) Syarif Hidayatullah.

Noupal, Muhammad "Kontroversi Tentang Sayyid Utsman Bin Yahya (1822-1914) Sebagai Penasehat Snouck Hurgronje" dalam Conference Proceedings: Annual International Conference on Islamic Studies 
(AICIS XII), 5-8 November 2012, Surabaya - Indonesia.

Noupal, Muhammad. "Kritik Sayyid Utsman bin Yahya Terhadap Gerakan Pembaharuan Islam di Indonesia : Studi Sejarah Islam di Indonesia Abad 19 dan Awal Abad 20", dalam JIA Desember 2013, Th.XIV, No. 2.

Steenbrink, Karel A. 1984. Beberapa Aspek Tentang Islam di
Indonesia. Jakarta: Bulan Bintang.

Usman, Abdullah bin. tt. Suluh Zaman. Jakarta: Percetakan Sayyid Usman.

Usman, Sayyid. tt. Dzikru Masyaikh alMu'allif. Manuskrip.

Zulkifli. 2013. The Struggle of the Shi is in Indonesia. Canberra: ANU E Press. 